\title{
Do Talent Management Practices Affect Organizational Culture?
}

\author{
M. LUTFI AL- DALAHMEH ${ }^{1}$, K. DAJNOKI ${ }^{2}$ \\ ${ }^{1}$ University of Debrecen, Faculty of Economics and Business, Department of Human Resource \\ Management, Mahalutfi87@gmail.com \\ ${ }^{2}$ University of Debrecen, Faculty of Economics and Business, Department of Human Resource \\ Management, dajnoki.krisztina@econ.unideb.hu
}

Abstract: The purpose of this paper is to enhance the readers' understanding of the domain of talent management and organisational culture and how talent management becomes one of the important strategic tools to improve the work environment, specifically as a tool for enhancing the organizational culture. The paper also attempts to probe and aid readers in understanding to what extent talent management affects the organizational culture. This paper is based on secondary research and articles in the areas of talent management, organizational culture and the relationship between them. The author has reviewed the existing body of work on these topics to arrive at the analysis of the relationship between talent management and organizational culture. As well as measuring its impact on the whole organization by reviewing the existing literature.

Keywords: Human Resources Management, Organizational culture, Development, Retaining

JEL Classification: 015

\section{Introduction}

According to global economic and demographic trends and changes, an increasing global collaboration between multinational organizations and extending workforce diversity is needed to find out ways to attract and retain talented employees (Collings et al, 2019). The world of businesses has been affected by these changes in the nature of work as well as the management style and applied management practices, - also seems that in the ERP (Enterprise Resource Planning) systems since the Human Resource Management module belongs to its core component (Debrenti et al., 2019) -, which will generate the development of new knowledge, increased competition, innovation within the borders of the existing organizational culture in the organization (Van den Broek et al., 2018). From a social perspective, an organization's culture is a living system that is a matter of priority for those managers who want to build a strong structure of norms and values within an organization. While sharing it to those working in different levels within the organization, to become not only a system of thinking approach but protrude the "life" of an organization (Raharjo et al, 2018). 
Most of the successful organizations recognized that practices of talent management directly affect the organization's culture and strategy (Sheehan \& Anderson, 2015), so they try to use it as a tool to shape the culture and values (Anlesinya, Dartey-Baah, \& Amponsah-Tawiah, 2019).

Moreover, an effective talent management strategy is not considered as a responsibility of just one individual but a collective responsibility of multiple stakeholders which intersects with the core value of organizational culture (Sheehan \& Anderson, 2015). The organizations that care about their employees as a valuable and fixed asset can adapt and work easily when business environment changes to be unsustainable and unpredictable (Krishnan \& Scullion, 2017), In recent years the organizations which are capable of succeeding in the market, are the organizations which have realized that the main component of the new basis of human resources capital is the creation of a mentality focused on talented valuable employees who have technical competencies(Armstrong,2017). They make this mentality an essential part of the organizations culture and strategy (Kontoghiorghes, 2016). Furthermore, not only the nature of the labour shortage affects employers and organizations negatively, but the issue of talented shortage has become the most sensitive issue (Héder, 2017).

Given the lack of existing research addressing the relationship between talent management challenges and organizational culture, an inductive approach was adopted, involving reviewing in-depth researches which discuss both of these concepts, how they affect each other. Thus, for this purpose this article has collected and integrated the existing studies to illustrate this relationship.

\section{Literature Review}

\subsection{Talent management}

Before starting to define the concept of talent management, the definition of talent must be noted first. Talent is a discussed concept in the fields of psychology and education which is closely related and people with high IQ (Beechler \& Woodward,2009). However, talent has been used in business and management, often to point out individual high performance and productivity (Silverman, 2012).

Through the several huge changes in the stages of economic development, human ability did not have one shape. In the beginning, they were focused on the physical ability of the worker. Later aligning with the increasing concern in the market and customer needs, it turned to focus on the skilled workers and their skills in the general markets (Kibui et al., 2014).

Thus, talent represents an important area of competition and one of the main sources of competitive advantage (Wellins et al., 2010). There is no one general adopted definition for talent in business literature and studies, depending on the researchers' perspectives, some of them proposed board definitions, the others proposed narrowed ones (Ashton and Morton, 2005).

According to Schiemann (2014) talent is defined as "The collective knowledge, skills, abilities, experiences, values, habits and behaviours of all labour that is brought to bear on the organization's mission", which is considered as the most common definition of talent. 


\subsection{Talent management}

The growing needs of the organizations to hire, attract, develop, and keep talented employees led to developing the concept of talent management until it became a strategic business challenge. (Ifeoma \& Purity, 2015) It has also obtained significant research concern recently, to build a theoretical and practical framework to illustrate this new concept, and opinions differ about the definition of talent management (Meyers, 2019). But after reviewing the literature it was found that the idea of the concept of talent management is not new, it has appeared in the research conducted by Mckinsey studies "talent war" after which it was developed to be published as a book in 2001 (Latukha, 2015).

There is no agreement between researchers on the definition of talent management, some researchers such as Boštjančič and Slana (2018) believe that talent management is not a new issue. However, it is a new label for employees' development by improve their skills, abilities, and knowledge (Collings \& Mellahi, 2009).

On the other hand, other researchers such as Lewis and Heckman (2006) believe that there is a new matter in TM by considering it as an essential component to effective planning to ensure an adequate flow of right employee into the right position throughout the organization ( Kibui et al., 2014).

Researchers presented many definitions of talent management, according to Lewis \& Heckman (2006), three points of view can be pointed out to define talent management., First, the reductionist view, which pointed out that talent management is a new label for the activities of HRM which is focused on high performing employees (Kibui et al., 2014), human resources management in the past focused to attract, develop, and keep skilled workers (Thunnissen, 2016), but today it concerns about talented individuals (Waheed et al. ,2012). The second one is the functional and practical view, which pointed TM as the last stage in the evolution of human resources management processes and it has several specialized functions such as planning, training, maintaining employees ....etc (Krishnan \& Scullion, 2017). In the economies which are based on knowledge, there are other functions done by the HRM such as attracting, developing, and assessing talent (Vaiman et al. , 2015), and it means having the right employees at the right time to the right position (Ashton \& Morton, 2005). Third view, the strategic view: where talent management is a new pattern of HRM which focused on talented people and considered them as a strategic asset (Collings \& Mellahi, 2009a), in this perspective, talented people are those people who can make a difference at the strategic level, and create a competitive advantage and invest in the strategic opportunities, and raise the company's market value using human capital. These contributions come as the responsibility and priorities of top management (Ifeoma \& Purity, 2015).

\section{3 Talent management approaches}

All employees are working in their organizations, even though they are not equal in terms of capabilities, experiences, and skills thus, some can be called high-performance leaders and some 
of those are low-performance ones. In this situation, challenges are imposed on the organization related to how to deal with these employees (Thunnissen, 2016).

In general, there are two approaches mentioned in the literature to evaluate talent management. First, the exclusive approach which can be explained by the Pareto rule (20/80), which means that the organization focus on what is called "star employees" (Böhmer \& Schinnenburg, 2016) who have high performers regardless of other employees, this approach does not support the organization to improve the largest number of employees and take advantage of them, and it could increase the turnover percentage and reduce the engagement(Salau et al., 2018). The second approach focuses on all employees in the organization to improve their skills and capabilities (Collings \& Mellahi, 2009).

Many types of researches have given definitions of TM (Collings and Mellahi 2009; Lockwood 2006; Lewis and Heckman, 2006), most of these definitions clarified that TM consists of a set of functions, such as planning, attracting, retaining, motivating, developing talent (Story et al., 2016). These functions are important to define the basic activities of talent management because it is a broad concept which covers many activities and dimensions of the relationship of organizations with talented people (Krishnan \& Scullion, 2017; Collings \& Mellahi, 2009).

In general, researchers such as Collings and Mellahi (2009a) have a different opinion as mentioned before in identifying these functions , however, they have agreed that these functions should be aligned with the HRM strategy (Anlesinya et al., 2019). The figure 1. illustrate these functions of talent management according to researches opinions in the literature.
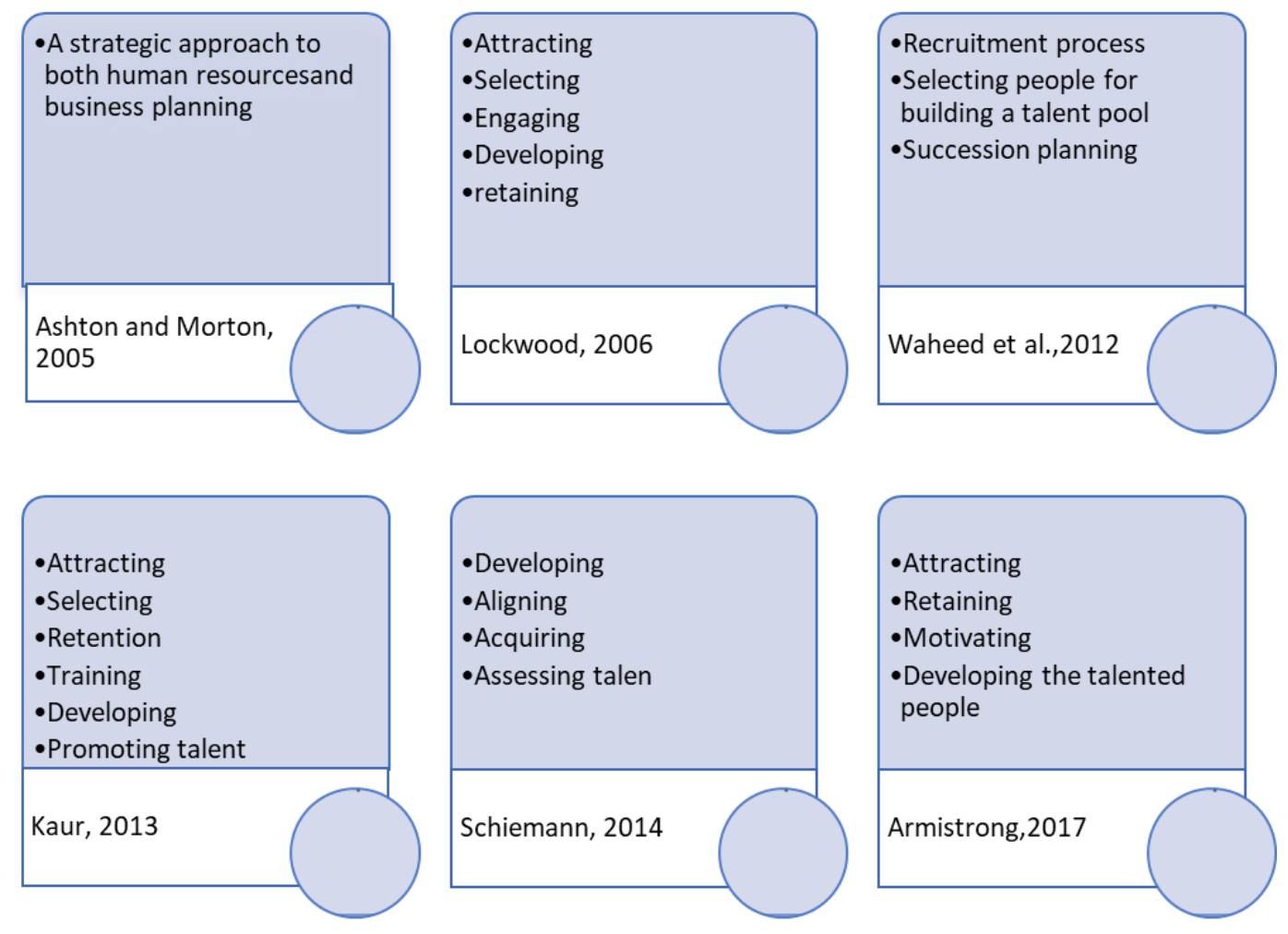

Figure1: Talent management functions

Source: own editing 
All the previous researchers have agreed that talent Management generally refers to the activities of attracting, developing and retaining the best employees. However, the concept is often used interchangeably with human resources management, and they also ensured that talent management uses strategic human resource planning to enhance business value to help the organizations achieve their goals (Kaur,2013), furthermore, talent management strategy should be linked to the main business strategy to function more appropriately (Stahl et al.,2012).

\subsection{Organizational culture concept}

The concept of organizational culture, which is simply called 'culture', is difficult to define. This difficulty partly comes from the wide and many uses of the term culture, and also from the fact that most of the culture is hidden from the eye and it needs to be analysed to be defined (Raharjo et al., 2018). The majority of practitioners and academics who studied organisations said that the concept of culture is the general means of the climate and practices that organisations improved it around their dealing with people, or to the shared values and statement of beliefs of an organisation (Chong et al., 2018). Schein (2004) indicated that the only thing of core importance that managers do is to create and manage culture within their organisations; that the unique talent of managers is their ability to understand, adapt, and work in the terms of that culture.

Organisational culture consists of different aspects such as observable patterns of behaviours and symbols, in addition to the underlying deep values, assumptions, and beliefs. Some researches argue that organisational culture can be changed and developed by focusing on the more visible patterns such as rituals, as these help in shaping behaviours (Baek, Chang, \& Kim, 2019). However, others argue that the concept of culture is not clarified enough as well as the deeper aspects of culture such as beliefs and feelings must be taken into consideration when the organisational culture and potential changes to culture are discussed (Chong et al., 2018). Corporate culture is intensely related to social environment that affects employees' behaviour, whereas culture also works and affects unconsciously through tying employees together and making them feel an essential part of the organization and pushing them to internalize their values and norms. Additionally, it helps employees to understand organizational systems and communicate efficiently as well as achieving higher levels of cooperation as they share common values and norms (Schein, 2009).

Like a coin, culture has two faces, the first one is visible which is characterized by external features like behaviours, code, processes, regulations, and dress, while the invisible face is deeply embedded within the organization and includes common beliefs, values, and norms in the organization (Aycan et al., 1999).

\subsection{Types of organizational cultures}

Organizational culture depends on many elements that could affect it, such as the size of the organization, type of business an organization is in, methods of operation, products, clients, and location (Chong et al., 2018). Many studies have been done and come out with different models for measuring culture based on dimensions of culture, such as the work of Cameron and Quinn 
(2011) Competing Values Framework (CVF), Handy Model, which is the common research found in the literature that is connected to the multitude of dimensions of cultural typologies as an alternative to find a simplified way of measuring cultures.

Typology of organizational culture has been discussed in the book of Hellriegel and Slocum (2010) titled Organizational Behaviour, and it has pointed out four types of organizational cultures; market culture, clan culture, entrepreneurial culture, and bureaucratic culture, and all types of cultures have been generated in the organization depending on their focus on control orientation and organization's pattern (Hellriegel \& Slocum, 2010, Cameron \& Quinn, 2011):

Market culture: it is focused on the relationship between organization and employees based on agreements and contracts, thus the formal control orientation has a strong effect. Since the employees are expected to perform according to clear standards, the organization has to reward them based on the same standards, as the better performance employees will be rewarded in the form of increased remuneration (Naranjo-Valencia, Jiménez-Jiménez \& Sanz-Valle, 2011). The second type is Clan culture, which is characterized by focusing on tradition, self-management, personal commitment, and social influences. Employees in these organizations realize that their connection with the organization is only the salary in exchange for work, the loyalty reflected in being committed to this organization and working for a long time, in this type of culture senior clan members act as mentors for new employees, also Success in this type of organizations depends on teamwork (Cameron \& Quinn, 2011). The third is entrepreneurial culture, this culture depends on high levels of creativity and risk-taking. Employees demonstrate high levels of commitment to innovation and being on entrepreneurial initiatives following this culture, also organizations can react quickly to the changes and adapt because employees are promoted and rewarded for their initiatives, flexibility and growth prospects. Control orientation is flexible to enhance innovation and change (Hellriegel \& Slocum, 2010). Finally, bureaucratic culture, organizations which depend on bureaucratic culture depend also on standard operating frameworks, formal rules, hierarchical management, and with a focus on efficiency and stability, behavioural norms follow written rules and standards, also tasks, responsibilities, authority for all employees are well defined and specified, so all the staff follow the regulations as it is (Karimi \& Kadir, 2012).

The use of typologies in cultural studies is challenging although they are easier to realize because the main weakness in their method is the inability of real situations to connect with any single typology. According to the studies it is not easy to implement talent management activities in the organizations that depend on the clan culture (Hellriegel \& Slocum, 2010).

The competing values framework ( $\mathrm{CVF}$ ) was based on a research to examine factors of organizational effectiveness (Quinn and Rohrbaugh, 1983), besides, this model helps to integrate most organizational culture dimensions which must be flexible and adaptable but being controlled and stable at the same time. According to this framework there are four types of organizational culture which is clan, adhocracy, hierarchy, and market. Clan culture focuses on the collaboration and drives values which are related to commitment, communication and development and it relies on human development and high commitment to generate effectiveness, while the adhocracy culture focuses on creating and innovation, and it believes that 
innovativeness, vision, and constant change produce effectiveness ( $\mathrm{Yu}, 2009)$. Hierarchy culture emphasizes that control is the main player in the organizations and addressed efficiency, timeliness, consistency, and uniformity as core values and through these values, the organization can enhance the effectiveness (Lamond, 2003). Finally, the market culture is oriented to compete and focus on values that increase market share and helps in achieving goals and profitability, and the organization can produce effectiveness through focusing on the customer and aggressively competing (Quinn and Rohrbaugh, 1983).

Along with trying to find a connection between talent management functions and activities and the competing values framework (CVF), it seems that they meet at some point in adhocracy and market culture; because they have the common value which focuses on moving the organization to be more innovative and more flexible to reach organization goals which are profitability and effectiveness.

\subsection{The relationship between talent management and organizational culture}

The organizational culture has a highly essential effect on managing talents, it is not enough to identify, retain, develop talented employees but also it is important to establish organizational culture that supports the development of talented employees (Raharjo et al., 2018). Talent management provides a way to focus and facilitate its' tools, which has started to install a talent mindset in the culture of an organization, with focusing on employee's engagement (Ashton and Morton, 2005; Héder, 2018),

Aycan et al. (1999) connected different functions with organizational cultures such as control, motivation and competitive advantage and conflict resolution, while Greenberg and Baron (2003) have a different opinion about functions of organizational culture. They pointed out that culture gives an identity, which generates organizational commitment that goes with the mission of the organization. They also highlight that culture affects employees' behaviours in the organization which results in higher performance. Organizations have to realize that some external and internal factors and challenges which call for a cultural adaptation for external ones and, internal integration for internal factors. To create this adaption and integration, organizations should develop a strategic mission and goals, which could be implemented thoroughly by empowering employees, so that organizations can proactively take adaptive procedures, which could be achieved by having a common and general language understood by all employees which will develop connections channels within the organization (Al Suwaidi \& Rahman, 2019).

Baek et al. (2019) argued that organizations do not necessarily have only one type of culture, it could have different cultures according to regulations and rules, the nature of business, goals, policies, and personalities of individuals employed in the organization. Thus, organizational culture is one of the factors which affect talent management as discussed also by Wilska (2014). The corporate culture that supports the development of human resources is essential and important to effective talent management also corporate cultures where managers are involved 
at all levels in the enhancement of talent have a massive effect on the overall talent management process in the organization (Collings \& Mellahi, 2009).

Organizational culture affects talent management at three levels starting from recruitment, the development until retention (Caver \& White, 2013), recruitment and selection is the first meeting for a candidate with the organization so it should leave a positive impression on the candidate. This way organizational culture influences the recruitment process. Development is a significant process in talent management, where organizations should be committed to developing talented members within the organization from day one for the employee and throughout his work with the organization. This commitment from the organizations toward the employees will motivate them to give better performance (Anlesinya et al., 2019). Also, talent retention is a very important factor in the talent management process, wherein unpredictable working environment organizations need productive, engaged and loyal employees more than before; thus, organizational culture that supports, encourages and maintains connections for employees surely has greater impact on the individuals who want to work in such organizations (Sonnenberg, van Zijderveld, \& Brinks, 2014).

Egerova (2013) indicated that there is a new approach which is called integrated talent management and defines it as a comprehensive approach that supports an organization in reacting to changes in the business environment flexibly. This approach connects the concepts of human resource strategy, business strategy, talent management, and organizational culture. This integration with organizational culture represents that the values and vision of talent management processes are closely connected with the values of organizational culture.

Talent management is related to implementing organizational strategies to enhance productivity through improved processes to attract, develop, retain, and hire individuals with specific skills to meet business requirements (Muduli, 2008). According to that both talent management strategy and organizational strategy stem from the main organization strategy (Sheehan \& Anderson, 2015). Increasingly, organizational cultures and talent management practices become first to be focused on practices that develop employees' behaviours in general; thus, organization's culture is a matter of priority for managers who try to establish strong relationships in their organization through integrating management principles into talent management strategies (Anlesinya et al., 2019).

\section{Conclusions}

This article aims to enhance the understanding of the relationship between talent management and organizational culture through building a theoretical framework to clarify the factors which also affect this kind of relationship. The literature tend to agree on the important role of culture in overall talent management processes, where talent management is vital for organizations, and it is widely connected with human resource activities. Researchers have extended the perspective by connecting various other practices with talent management to give it a comprehensive approach. Organizational culture is also deeply connected with the core values and norms system of any organization, and managers who are accountable for implementing it. 
However, these values could be reflected by the employees' daily activities as a culture. It is agreed that the organizational culture alignment of business strategy is also of great importance to obtain a competitive advantage and improve the performance of the list in organizations but it is important that leaders of the organization make it effective. By keeping eyes on successful organization, it has been found that the integrated approach to talent management connects to values of organizational culture, also managers should participate in putting strategic aids in effective talent management. The literature also shows that employees will perform better in organizations with a positive culture. Managers should realize the role of culture in an organization and how it could help recruit, develop and train talented employees that best fit for an organization, and those that have the best competencies to perform functions for the job.

Ultimately, the literature focus on clarifying the relationship between talent management and organisational culture but most of the studies analysed how organizational culture could affect the talent management process and it found that they are deeply connected in an inverse relationship, which could be a further area for future research.

\section{Acknowledgment}

The publication is supported by the EU-funded Hungarian grant EFOP-3.6.3.-VEKOP-16-201700007, for the project entitled "From Talent to Young Researchers" - Supporting the Careerdeveloping Activities of Researchers in Higher Education.

\section{References}

[1] Al Suwaidi, A. A., \& Rahman, M. H. (2019): Organizational Culture, Leadership and Performance in Dubai Municipality.

[2] Anlesinya, A., Dartey-Baah, K., \& Amponsah-Tawiah, K. (2019): Strategic talent management scholarship: a review of current foci and future directions. Industrial and Commercial Training, 51(5), 299-314.

[3] Armstrong, M. (2017): „Armstrong's Handbook of Human Resource Management Practice” Kogan Page Publishers, London and Philadelphia, 14th edition, 738.p.

[4] Ashton, C., \& Morton, L. (2005). Managing talent for competitive advantage: Taking a systemic approach to talent management. Strategic HR Review, 4(5), 28-31.

[5] Aycan, Z., Kanungo, R. N., \& Sinha, J. B. (1999). Organizational culture and human resource management practices: The model of culture fit. Journal of cross-cultural psychology, 30(4), 501-526.

[6] Baek, P., Chang, J., \& Kim, T. (2019). Organizational culture now and going forward. Journal of Organizational Change Management, ahead-of-print(ahead-of-print).

[7] Beechler, S. \& Woodward, I. C. (2009): The global "war for talent". Journal of International Management, (15): 273-285. 
[8] Böhmer, N., \& Schinnenburg, H. (2016): How gender and career concepts impact Global Talent Management. Employee Relations, 38(1), 73-93.

[9] Boštjančič, E., \& Slana, Z. (2018): The role of talent management comparing medium-sized and large companies - Major challenges in attracting and retaining talented employees. Frontiers in Psychology, 9(SEP).

[10] Cameron, K. \& Quinn, R. (2011): Diagnosing and hanging Organizational Culture, San Francisco: Jossey - Bass.

[11] Caver, K. \& White, R., (2013): Aligning Organizational Culture with Business Strategy, New York, Towers Watson.

[12] Chong, M. P. M., Shang, Y., Richards, M., \& Zhu, X. (2018): Two sides of the same coin? Leadership and organizational culture. Leadership and Organization Development Journal, 39(8), 975-994.

[13] Collings, D. G., \& Mellahi, K. (2009): Strategic talent management: A review and research agenda. Human Resource Management Review, 19(4), 304-313.

[14] Collings, D. G., Mellahi, K., \& Cascio, W. F. (2019): Global Talent Management and Performance in Multinational Enterprises: A Multilevel Perspective. Journal of Management, 45(2), 540-566.

[15] Debrenti A., S., Csordás A., \& Herdon M. (2019): Management support systems in the Hungarian food manufacturing sector, Agrárinformatika / Journal Of Agricultural Informatics 10: 1 pp. 21-32. , 12 p. (2019).

[16] Egerova, D. (2013), Integrated Talent Management - A Challenge or Necessity for Present Management. Problems of Management in 21st Century, 9(2): 114-128.

[17] Héder M. (2017): Munkaerő- vagy tehetséghiány? - Fogalmi különbségek feltárása a hatékony gyakorlati alkalmazás érdekében. International Journal of Engineering and Management Sciences 2:4180-190. Paper: DOI: 10.21791/IJEMS.2017.4.15

[18] Héder M. (2018): Tehetségmenedzsment a nemzetközi gyakorlatban Európa és Kína példáján keresztül. International Journal of Engineering and Management Sciences 3:4. 454-464.

[19] Hellriegel, D. \& Slocum, J. (2010), Organizational Behavior,Ohio, South Western Cengage Learning Inc.

[20] Ifeoma, R. O., \& Purity, N.O. (2015): Effective Talent Management: Key to Organisational Success. Journal of Policy and Development Studies (Vol. 9).

[21] Karimi, Y., \& Latifah Abdul Kadir, S. (2012). The Impact of Organisational Culture on the Implementation of TQM: Empirical Study in the Iranian Oil Company. American Journal of Industrial and Business Management, 02(04), 205-216.doi: 10.4236/ajibm.2012.24027. 
[22] Kaur, R. (2013): Empirical study of talent management program and its impact on the employee's retainment and performance in Indian supermarket big bazaar, Human Resource Management Research, 3(3): 61- 70.

[23] Kibui, A. W., Gachunga, H., \& Namusonge, G. S. (2014). Role of Talent Management on Employees Retention in Kenya: A Survey of State Corporations in Kenya : Empirical Review. $3(2), 414-424$.

[24] Kontoghiorghes, C. (2016). Linking high-performance organizational culture and talent management: satisfaction/motivation and organizational commitment as mediators. The International Journal of Human Resource Management, 27(16), 1833-1853.

[25] Krishnan, T., \& Scullion, H. (2017): Talent management and dynamic view of talent in small and medium enterprises. Human Resource Management Review, 27(3), 431-441.

[26] Lamond, D. (2003): The value of Quinn's competing values model in an Australian context. Journal of Managerial Psychology, 18(1-2), 46-59.

[27] Latukha, M. (2015): Talent management in Russian companies: domestic challenges and international experience. International Journal of Human Resource Management, 26(8), 1051-1075.

[28] Lewis, R. E. \& Heckman, R. J. (2006): Talent management: A critical review. Human Resource Management Review, 16(2), 139-154.

[29] Lockwood, N. R. (2006): Talent management: Driver for organizational success, HR Magazine, 51(6): 1-11.

[30] Meyers, M. C. (2019): The neglected role of talent proactivity: Integrating proactive behavior into talent-management theorizing. Human Resource Management Review, 100703.

[31] Naranjo-Valencia, J. C., Jiménez-Jiménez, D., \& Sanz-Valle, R. (2011): Innovation or imitation? The role of organizational culture. Management Decision, 49(1), 55-72.

[32] Raharjo, K., Nurjannah, S. \& Achmad Rinaldo Fernandes, A. (2018): The influence of organizational culture and job design on job commitment and human resource performance. Journal of Organizational Change Management, 31(7), 1346-1367.

[33] Salau, O., Osibanjo, A., Adeniji, A., Oludayo, O., Falola, H., Igbinoba, E., \& Ogueyungbo, O. (2018): Data regarding talent management practices and innovation performance of academic staff in a technology-driven private university. Data in Brief, 19, 1040-1045.

[34] Schein, E.H. (2004): Organizational Culture and Leadership, Third edition, San Francisco: Jossey-Bass.

[35] Schein, E. (2009): The Corporate Culture Survival Guide - New and Revised Edition, San Francisco: Jossey Bass.

[36] Schiemann, W. A. (2014): From talent management to talent optimization, Journal of World Business, 2014,49: 281-288. 
[37] Sheehan, M., \& Anderson, V. (2015): Talent Management and Organizational Diversity: A Call for Research. Human Resource Development Quarterly, 26(4), 349-358.

[38] Silverman, L . (2012): Giftedness 101, New York: Springer Publishing Company, 2012.

[39] Sonnenberg, M., van Zijderveld, V., \& Brinks, M. (2014): The role of talent-perception incongruence in effective talent management. Journal of World Business, 49(2), 272-280.

[40] Stahl, G., Björkman, I., Farndale, E., Morris, S. S., Paauwe, J., Stiles, P., \& Wright, P. (2012). Six principles of effective global talent management. Sloan Management Review, 53(2), 25-42.

[41] Story, J., Castanheira, F., \& Hartig, S. (2016): Corporate social responsibility and organizational attractiveness: Implications for talent management. Social Responsibility Journal, 12(3), 484-505.

[42] Thunnissen, M. (2016): Talent management: For what, how and how well? An empirical exploration of talent management in practice. Employee Relations, 38(1), 57-72.

[43] Vaiman, V., Haslberger, A., \& Vance, C. M. (2015): Recognizing the important role of selfinitiated expatriates in effective global talent management. Human Resource Management Review, 25(3), 280-286.

[44] Van den Broek, J., Boselie, P., \& Paauwe, J. (2018): Cooperative innovation through a talent management pool: A qualitative study on coopetition in healthcare. European Management Journal, 36(1), 135-144.

[45] Waheed, S., Zaim, A. \& Zaim, H. (2012): Talent management in four stages, The USV Annals of Economics and Public Administration, 1(15):130-137.

[46] Wellins, R. S., Liu, L., \& Qiuyong, T. (2010). The Talent Management Imperative Fueling China's Business Growth. Retrieved December 14, 2015, from http://www.ddiworld.com/ddi/media/trendresearch/chinatalentmanagementimperativ e_mis_ddi.pdf?ext=.pdf.

[47] Wilska, E. (2014): "Determinants of Effective Talent Management", Journal of Positive Management, 5(4): 77 - 88.

[48] Yu, T. (2009): A Review of Study on the Competing Values Framework Organizational culture change in China's privately-owned enterprises View project. 